\title{
LOCALIZATION OF GLYCEROPHOSPHATE ACYLTRANSFERASE IN ESCHERICHIA COLI
}

\author{
J.M.M. KESSELS, R.P.G.M. VAN DEN BREKEL, G. SCHRAKAMP and H. VAN DEN BOSCH \\ Laboratory of Biochemistry, State University of Utrecht, Transitorium III, Padualaan 8, NL-3584 CH Utrecht (The Netherlands)
}

(Reccived April 15th, 1982)

Key words: Subcellular localization; Glycerophosphate acyltransferase; (E. coli)

sn-Glycero-3-phosphate acyltransferase (EC 2.3.1.15) the first enzyme involved in phospholipid biosynthesis, is known to be associated with the cytoplasmic membrane of Escherichia coli. The localization of this enzyme in the transverse plane of the membrane was investigated by proteolysis of intact and lysed spheroplasts and by inhibition of glycerol 3-phosphate transport into intact cells in the presence of azide. Glycerophosphate acyltransferase was found to be resistent to proteolysis by trypsin in intact spheroplasts, whereas its enzymatic activity could be destroyed completely by trypsin in lysed spheroplasts. These results are in line with a localization of the acyltransferase at the inner aspect of the cytoplasmic membrane. Sodium azide was shown to have no inhibitory effect on glycerophosphate acyltransferase activity. Lack of incorporation of glycero phosphate into the phospholipids of glycerol phosphate transport-negative cells and inhibition of this incorporation in wild-type and glycerol 3-phosphate transport-constitutive cells by azide support a cytoplasmic-oriented localization of the glycerophosphate acyltransferase.

\section{Introduction}

The Gram-negative bacterium Escherichia coli is surrounded by a cell envelope consisting of an outer and an inner membrane [1]. The inner, cytoplasmic, membrane contains all enzymes involved in phospholipid biosynthesis [1-3], including CDPdiacylglycerol:L-serine $O$-phosphatidyltransferase (EC 2.7.8.8), which upon breaking the cclls shows a strong tendency to associate with ribosomes [4,5]. Virtually nothing is known about the localization of the active site of these membrane-associated enzymes in the transverse plane of the cytoplasmic membrane in procaryotes.

In liver cells the biosynthesis of phosphatidylcholine, phosphatidylethanolamine and triacylglycerol takes place at the cytoplasmic side of

Abbreviations: PPO, 2,5-diphenyloxazole; POPOP, 1,4-bis(2(5-phenyloxazolyl))benzene. the endoplasmic reticulum [6-9]. This asymmetric lipid synthesis on the cytoplasmic surface includes phosphatidate production from $s n$-glycerol 3-phosphate by $s n$-glycero-3-phosphate acyltransferase (EC 2.3.1.15, Refs. 7,9). On the other hand, the mitochondrial form of glycerophosphate acyltransferase in liver has been located on the inner aspect of the outer membrane [10,11].

Several observations in procaryotes also tend to suggest a cytoplasma-oriented localization of the enzymes involved in phospholipid biosynthesis in line with the production of water-soluble lipid precursors in the cytoplasma. In addition, autoradiographic studies have localized the putative acyl-donor protein, acyl-carrier protein, on or near the inside surface of the cytoplasmic membrane [12]. Rothman and Kennedy [13] demonstrated that newly synthesized phosphatidylethanolamine in Bacillus megaterium appeared first in the inner half of the membrane, whereafter a rapid equilibration with the phosphatidylethanolamine pool 
of the outer layer took place [13,14]. However, direct studies to localize the active site of glycerophosphate acyltransferase, the enzyme responsible for the first reaction of phospholipid biosynthesis in procaryotes, have not been reported. We report here on such studies carried out with $E$. coli.

\section{Materials and Methods}

Materials. DL-Glycerol 3-phosphate, E. coli K12 frozen cells, silica gel $G$ and silica gel $H$ were obtained from Merck, Darmstadt, F.R.G. Glucose 6-phosphate, $\mathrm{NADP}^{+}$, trypsin, chymotrypsin, subtilisin, trypsin inhibitors from hen egg white and soybean, and lysozyme were purchased from Boehringer, Mannheim, F.R.G. L- $\left[\mathrm{U}^{-14} \mathrm{C}\right]$ Glycerol 3-phosphate $(177 \mathrm{mCi} / \mathrm{mmol})$ was a product of the Radiochemical Centre, Amersham, U.K. Phospholipase $\mathrm{C}$ purified from Bacillus cereus was a gift from Dr. B. Roelofsen. Palmitoyl-CoA was synthesized according to the method of Al-Arif and Blecher [15].

Bacterial strains and growth conditions. Strains were obtained from Drs. J. Tommassen and J. Korteland from the Microbiology section of the Department of Molecular Cell Biology of this University. Strain CE 1061, a omp $\mathrm{C}^{+}$derivative of strain $\triangle B 1621$ [16] is wild-type with respect to glycerol 3-phosphate transport and lipid biosynthesis and will be indicated as such. Strain LA 5001 is a glycerol 3-phosphate transport-negative mutant [17]. Strain JBO 52 is a pho A derivative of strain CGSC 6318 [18] and is constitutive for glycerol 3-phosphate transport (Korteland, J., unpublished data). Cells were grown until late $\log$ phase in a medium containing per 1: $10 \mathrm{~g}$ bactopeptone, $10 \mathrm{~g}$ yeast extract, $1 \mathrm{~g} \mathrm{Na}{ }_{2} \mathrm{HPO}_{4} \cdot 2 \mathrm{H}_{2} \mathrm{O}$, $5 \mathrm{~g} \mathrm{NaCl}$ and $20 \mathrm{mg}$ each of guanine, adenine, thymine and uracil. Growth temperature was $37^{\circ} \mathrm{C}$, except for strain LA 5001 which was cultured at $30^{\circ} \mathrm{C}$. Cells were harvested by centrifugation at $15000 \times g$ in a Sorvall RC2-B centrifuge and washed twice with $30 \mathrm{mM}$ Tris- $\mathrm{HCl}(\mathrm{pH} \mathrm{8.4)}$ containing 20\% (w/v) sucrose.

Membrane preparation. Cells from $500 \mathrm{ml}$ culture medium were harvested by centrifugation and washed with a solution containing $20 \%(\mathrm{w} / \mathrm{v})$ sucrose and $30 \mathrm{mM}$ Tris- $\mathrm{HCl}(\mathrm{pH} 8.0)$. Cells were resuspended in $10 \mathrm{ml}$ of this solution and broken by sonication for $5 \mathrm{~min}$ at $70 \mathrm{~W}$ in an ice bath. Cell debris was removed by centrifugation at 5000 $\times g$, whereafter membranes were pelleted by ultracentrifugation for $60 \mathrm{~min}$ at $100000 \times \mathrm{g}$. The membranes were resuspended in $2.5 \mathrm{ml}$ of a solution containing $100 \mathrm{mM}$ Tris- $\mathrm{HCl}(\mathrm{pH} 8.4), 0.4 \mathrm{M}$ $\mathrm{NaCl}, 20 \%$ (v/v) glycerol, $5 \mathrm{mM} \beta$ mercaptoethanol and $5 \mathrm{mM} \mathrm{MgCl}_{2}$ and stored at $-20^{\circ} \mathrm{C}$ until use.

Extraction and reconstitution of glycerophosphate acyltransferase. Glycerophosphate acyltransferase was extracted from wild-type $E$. coli $\mathrm{K} 12$ cells with Triton X-100 by a modification of the procedure of Snider and Kennedy [19]. Reconstitution of enzymatic activity was done by a cholate gel filtration technique as described originally for the preparation of single bilayer lipid vesicles by Brunner et al. [20]. Details of these procedures will be published clsewhere.

Spheroplasts. Spheroplasts were prepared by a modification of Kaback's procedure [21]. To $10 \mathrm{ml}$ of a suspension of washed cells ( $1 \mathrm{~g}$ wet weight $/ 80$ $\mathrm{ml})$ in $30 \mathrm{mM}$ Tris- $\mathrm{HCl}(\mathrm{pH} 8.0) / 20 \%(\mathrm{w} / \mathrm{v})$ sucrose, 0.1 vol. of $0.1 \mathrm{M}$ EDTA and 0.01 vol. of 5 $\mathrm{mg} / \mathrm{ml}$ lysozyme, each in the Tris/sucrose solution, were added while stirring at room temperature. Spheroplast formation was followed according to the method of Yamato et al. [22] After 30 min less than $5 \%$ of intact cells remained. Spheroplasts were isolated by centrifugation for 10 min at $3000 \times g$ and resuspended in $40 \mathrm{ml}$ of Tris/sucrose buffer. When lysed spheroplasts had to be prepared the pellet was resuspended in 30 $\mathrm{mM}$ Tris- $\mathrm{HCl}(\mathrm{pH} \mathrm{8.0)}$.

Incubations with proteolytic enzymes. To $39 \mathrm{Iml}$ of intact or lysed spheroplasts was added $1 \mathrm{ml}$ of a trypsin, chymotrypsin or subtilisin solution $(5 \mathrm{mg}$ enzyme $/ \mathrm{ml}$ in $20 \%$ sucrose $/ 1 \mathrm{mM} \mathrm{CaCl}_{2} / 10 \mathrm{mM}$ $\mathrm{KCl}$ adjusted to $\mathrm{pH} 3.0$ ). The mixture was incubated for $60 \mathrm{~min}$ at $25^{\circ} \mathrm{C}$. After the indicated time periods aliquots were removed and proteolytic action was stopped by addition of inhibitors. Trypsin was inhibited by hen egg white inhibitor (trypsin: inhibitor, 1:2(w/w)), while chymotryp$\sin$ action was stopped by addition of soybean trypsin inhibitor (chymotrypsin: inhibitor, 1:5 $(w / w))$. Subtilisin action was stopped by adding $0.1 \mathrm{M}$ diisopropylfluorophosphate in isopropanol 
(final concentration $0.5 \mathrm{mM}$ ) followed by $20 \mathrm{~min}$ incubation at $25^{\circ} \mathrm{C}$. All samples were sonicated for 2 min at $0^{\circ} \mathrm{C}$ prior to determination of residual enzymatic activities to ensure abolition of latency.

Enzyme assays. Glucose-6-phosphate dehydrogenase was assayed according to the method of Banerjee and Fraenkel [23] in a volume of $1.0 \mathrm{ml}$ containing $9 \mathrm{mM} \mathrm{MgCl}_{2}, 0.18 \mathrm{mM} \mathrm{NADP}^{+}$and 1 $\mathrm{mM}$ glucose 6-phosphate. The absorbance change at $340 \mathrm{~nm}$ and $25^{\circ} \mathrm{C}$ was measured against a reference cuvette lacking glucose 6-phosphate. Enzymatic activity in spheroplast preparations was measured in $30 \mathrm{mM}$ Tris- $\mathrm{HCl}(\mathrm{pH} 8.0) / 20 \%(\mathrm{w} / \mathrm{v})$ sucrose, while those in lysed spheroplasts were measured in $30 \mathrm{mM}$ Tris- $\mathrm{HCl}(\mathrm{pH} \mathrm{8.0)}$. The percentage leaky spheroplasts is defined as (absorbance change in intact spheroplasts/absorbance change in lysed spheroplasts) $100 \%$. Glycerophosphate acyltransferase activity was determined under conditions as described by Snider and Kennedy [19]. The incubation mixture contained $1 \mathrm{mg} / \mathrm{ml}$ bovine serum albumin, $43 \mu \mathrm{M}$ palmitoyl-CoA, $1.25 \mathrm{mM} s n$ - $\left[{ }^{14} \mathrm{C}\right]$ glycerol 3-phosphate (spec. radioact. $400 \mathrm{cpm} / \mathrm{nmol}$ ), $1.25 \mathrm{mM}$ sn-glycerol 1-phosphate, $0.1 \mathrm{M}$ Tris- $\mathrm{HCl}(\mathrm{pH} 8.4)$, $0.4 \mathrm{M} \mathrm{NaCl}, 5 \mathrm{mM} \mathrm{MgCl} 2,5 \mathrm{mM} \beta$-mercaptoethanol and $20 \%(\mathrm{v} / \mathrm{v})$ glycerol in a total volume of $125 \mu 1$. After $20 \mathrm{~min}$ incubation at $30^{\circ} \mathrm{C}$, unless indicated otherwise, an aliquot of $100 \mu \mathrm{l}$ was transferred to a filter paper disk and processed as described by Van den Bosch and Vagelos [24]. Radioactivity was measured in $10 \mathrm{ml}$ of scintillation liquid (5 g PPO and $0.25 \mathrm{~g}$ POPOP $/ 1$ toluene) using a Searl Isocap 300 liquid scintillation spectrometer.

Product analysis of glycerol 3-phosphate incorporation in cells. After incubation the cells were cooled to $0^{\circ} \mathrm{C}$ and harvested by centrifugation for $15 \mathrm{~min}$ at $6500 \times \mathrm{g}$. The pellet was washed with 30 $\mathrm{mM}$ Tris- $\mathrm{HCl}(\mathrm{pH} \mathrm{8.0)/20 \%} \mathrm{(w/v)} \mathrm{sucrose.} \mathrm{After}$ addition of an estimated 10 -fold excess of unlabeled $E$. coli lipid, the total lipid was extracted according to the method of Bligh and Dyer [25]. The lipids were separated on silica gel $\mathrm{H}$ plates impregnated with $\left(\mathrm{NH}_{4}\right)_{2} \mathrm{SO}_{4}$ as described by Benns and Proulx [26]. Spots were detected by iodine vapor and scraped into $14 \mathrm{ml}$ of Packard Emulsifier for radioactivity determination. In some experiments the $\left[{ }^{14} \mathrm{C}\right]$ glycerol distribution over acylated backbone and polar headgroup glycerol of phosphatidylglycerol was determined by established procedures following phospholipase $\mathrm{C}$ degradation of the phosphatidylglycerol. Radioactivity in diacylglycerols obtained after phospholipase $\mathrm{C}$ degradation was determined after separation from residual phosphatidylglycerol by TLC using silica gel $\mathrm{H}$ plates and $\mathrm{CHCl}_{3} / \mathrm{CH}_{3} \mathrm{OH} / \mathrm{H}_{2} \mathrm{O}$ $(70: 35: 4, v / v)$ as developing solvent.

\section{Results and Discussion}

Latency experiments. The results in Table I show that disruption of the permeability barrier in either cells or spheroplasts gives rise to a $5-10$-fold increase in the incorporation of glycerol 3-phosphate in $E$. coli lipids. Low incorporation of radioactivity

\section{TABLE I}

INCORPORATION OF GLYCEROL 3-PHOSPHATE IN E. COLI TOTAL LIPIDS

$\left[{ }^{14} \mathrm{C}\right]$ Glycerol 3-phosphate incorporation was measured by the filter paper assay using identical amounts of either intact or disrupted cells or spheroplasts and 20 -min incubations. Disruption was obtained by sonication. Values of two experiments are given.

\begin{tabular}{|c|c|c|c|c|}
\hline \multirow[t]{3}{*}{ Strain } & \multicolumn{4}{|c|}{$\left[{ }^{14} \mathrm{C}\right]$ Glycerol 3-phosphate incorporated (dpm) } \\
\hline & \multicolumn{2}{|c|}{ Washed cells } & \multicolumn{2}{|c|}{ Spheroplasts } \\
\hline & Intact & Disrupted & Intact & Disrupted \\
\hline Wild-type & 126,123 & 625,631 & 113,123 & 510,482 \\
\hline JBO 52 & 222,234 & 616,648 & 110,95 & 555,614 \\
\hline LA 5001 & 162 & 405,381 & 51,57 & 621,585 \\
\hline
\end{tabular}


is observed in cells of strain LA 5001, a glycerol 3-phosphate transport-negative mutant. More than $85 \%$ of the incorporated radioactivity was recovered in the backbone of phosphoglycerides. These results suggest latency, and hence an intracellular localization of the glycerophosphate acyltransferase. In these experiments the permeability barrier was broken by sonication for $2 \mathrm{~min}$. Control experiments (data not shown) have indicated that optimal stimulation of $\left[{ }^{14} \mathrm{C}\right]$ glycerol 3-phosphate incorporation was obtained after sonication for $1 \mathrm{~min}$. Prolonged sonication for periods exceeding $2 \mathrm{~min}$ led to a decrease in incorporation so that a $10 \%$ lower value was found after 4 min sonication.

Proteolytic experiments. Initial experiments indicated that in the absence of added proteolytic enzymes neither in intact nor in lysed spheroplasts was a decrease in glucose-6-phosphate dehydrogenase activity observed during a $1 \mathrm{~h}$ incubation at $25^{\circ} \mathrm{C}$. This demonstrated that this intracellular marker is stable under the conditions of proteolytic treatment. The percentage leaky spheroplasts in freshly prepared spheroplasts as deduced from glucose-6-phosphate dehydrogenase latency amounted to $10-15 \%$ and this remained constant under the incubation conditions used for protease treatment. Fig. 1 demonstrates that treatment of intact spheroplasts with trypsin has little influence on the activities of both glucose-6-phosphate dehydrogenase and glycerophosphate acyltransferase. The small decrease in enzymatic activities can perhaps be explained by the presence of about

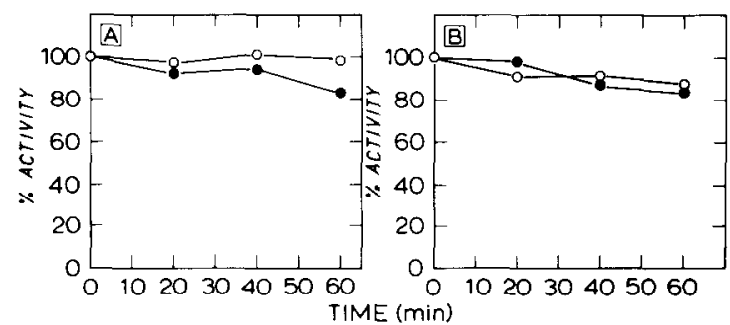

Fig. 1. Effect of trypsin treatment on enzymatic activities in intact spheroplasts. Intact spheroplasts were incubated for the indicated time periods at $25^{\circ} \mathrm{C}$ in the absence $(O)$ or presence (๑) of trypsin. After addition of trypsin inhibitor the samples were sonicated before measurement of residual glucose-6-phosphate dehydrogenase (B) and glycerophosphate acyltransferase (A) activity.

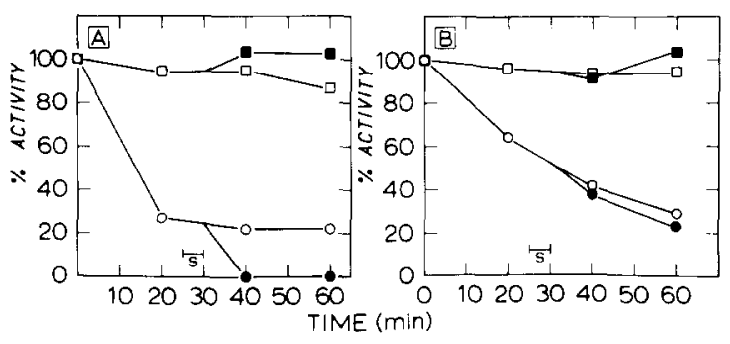

Fig. 2. Effect of trypsin treatment on enzymatic activities in lysed spheroplasts. Lysed spheroplasts were incubated at $25^{\circ} \mathrm{C}$ in the presence $(O)$ or absence $(\square)$ of trypsin. After $25 \mathrm{~min}$ half of the incubation mixture was removed, sonicated for $2 \mathrm{~min}$ at $0^{\circ} \mathrm{C}$ and then further incubated (closed symbols). After addition of trypsin inhibitor the samples were again sonicated before measurement of residual enzymatic activities. A, Glycerophosphate acyltransferase; B, glucose-6-phosphate dehydrogenase.

$15 \%$ leaky spheroplasts. By contrast, when lysed spheroplasts are incubated in the presence of trypsin (Fig. 2) the activity of both the intracellular marker and glycerophosphate acyltransferase is about $70-80 \%$ destroyed, while no loss of these activities is observed in the absence of trypsin. The plateau at about $20 \%$ residual activity reached in the studies on the susceptibility of the membranebound glycerophosphate acyltransferase to proteolysis might be due to resealing of membrane fragments in the lysed spheroplast preparation. Indeed, as indicated in Fig. 2A, sonication during the incubation with trypsin resulted in complete loss of glycerophosphate acyltransferase activity. The resistance of this enzyme to trypsin action in intact spheroplasts and its susceptibility in lysed spheroplasts point to a localization of glycerophosphate acyltransferase at the inner aspect of the cytoplasmic membrane. Similar experiments carried out with chymotrypsin and subtilisin to support this finding were inconclusive due to lysis of the spheroplasts in the presence of these proteolytic enzymes.

Inhibition of glycerol 3-phosphate transport. The bacterium $E$. coli has an inducible glycerol 3-phosphate transport system, by which intact glycerol 3-phosphate can be taken up from medium (for review see Ref. 27). This transport system is energy-dependent and is almost completely blocked in the presence of electron transport chain inhibitors such as azide [28]. We have attempted to use 


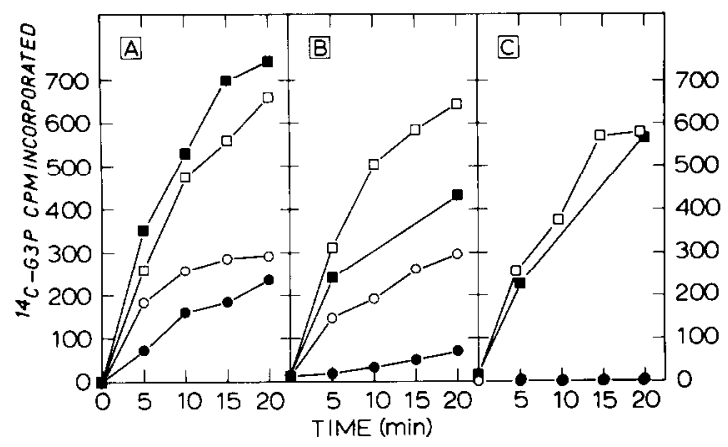

Fig. 3. Influence of sodium azide on glycerophosphate acyltransferase activity in intact and sonicated cells. Strains were grown to late $\log$ phase and $2-\mathrm{ml}$ samples were removed. These received sodium azide to a final concentration of $20 \mathrm{mM}$ (•) or an equivalent volume of buffer $(O)$. Of these mixtures $50-\mu 1$ samples were immediately removed and assayed for glycerophosphate acyltransferase activity for the indicated time periods. The remaining cell suspensions were sonicated for 2 min and $50-\mu 1$ aliquots were used to assay enzymatic activity

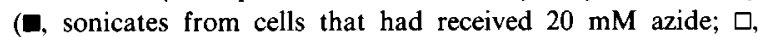
sonicates from control cells). A, wild-type E. coli; B, glycerol 3-phosphate transport-constitutive mutant JBO 52; C, glycerol 3-phosphate transport-negative mutant LA 5001: open and closed circles overlap in panel $\mathrm{C}$.

the energy-dependency of the glycerol 3-phosphate uptake to obtain more information on the localization of the active site of glycerophosphate acyltransferase in the transverse plane of the cell's envelope.

Although according to Boos et al. [29] the glycerol 3-phosphate-transport system is active in membrane vesicles we failed to demonstrate any appreciable inhibition by azide of glycerol 3-phosphate incorporation into phospholipids of either spheroplasts or washed cells. In agreement with the results of Nunn and colleagues [28], the energy-dependency of the transport system could easily be demonstrated in cells taken directly from the culture medium (Fig. 3). For the interpretation of these studies it is important to know that glycerol 3-phosphate incorporation into lipids of whole cells both in the presence and absence of azide represents de novo synthesis and hence can be used as an indicator of glycerophosphate acyltransferase activity. Table II shows results obtained with wild-type and glycerol 3-phosphate transport-constitutive JBO 52 cells. The distribution of radioactivity incorporated into phospholipids in the presence of azide is very similar to the pattern observed for each cell in the absence of azide. These radioactivity distributions differ considerably from the mass-distribution of phospholipids in E. coli (compare Ref. 1), presumably due to the presence of $1.25 \mathrm{mM}$ glycerol 3-phosphate in the assay medium. To investigate whether the large incorporation of glycerol 3-phosphate into phosphatidylglycerol is due to incorporation into the polar headgroup, this phospholipid was isolated and subjected to phospholipase $\mathrm{C}$ degradation. It can be seen from Table III that in all cases about $80 \%$ of the radioactivity is present in the diacylglycerol part of the molecule. It follows then from Table II that about $85 \%$ of the total glycerol 3-phosphate radioactivity incorporated

\section{TABLE II}

\section{DISTRIBUTION OF RADIOACTIVITY AMONG PHOSPHOI.IPID CLASSES}

Cells were incubated for $20 \mathrm{~min}$ with $\left[{ }^{14} \mathrm{C}\right.$ ]glycerol 3-phosphate in the absence and presence of azide as described in the legend to Fig. 3. Lipids were extracted from washed cells and analyzed. Results of two experiments (except for strain JBO 52, minus azide) are given.

\% Radioactivity in phospholipid of

\begin{tabular}{|c|c|c|}
\hline Wild type & & Strain JBO 52 \\
\hline - Azide & + Azide & - Azide \\
\hline
\end{tabular}

Phosphatidate plus cardiolipin

Phosphatidylglycerol Phosphatidylethanolamine

Remainder of TLC plate

$\begin{array}{rrrr}11,10 & 14,12 & 14 & 21,22 \\ 64,62 & 62,62 & 73 & 65,64 \\ 21,23 & 19,21 & 10 & 6,10 \\ 4,3 & 5,5 & 3 & 6,5\end{array}$




\section{TABLE III}

\section{DISTRIBUTION OF RADIOACTIVITY AMONG ACYLATED AND NON-ACYLATED GLYCEROL MOIETIES OF PHOS-} PHATIDYLGLYCEROL

Phosphatidylglycerol was isolated from cells incubated with $\left[{ }^{14} \mathrm{C}\right]$ glycerol 3-phosphate as described in the legend to Fig. 3. After virtually complete (over $90 \%$ ) degradation with phospholipase $\mathrm{C}$ the water-soluble and diacylglycerol radioactivity was determined. Results of two experiments (except for strain JBO 52, minus azide) are presented

\begin{tabular}{|c|c|c|c|}
\hline \multirow{2}{*}{$\begin{array}{l}\text { Phosphatidylglycerol } \\
\text { isolated from }\end{array}$} & \multicolumn{2}{|c|}{ Radioactivity distribution ( $\mathrm{dpm}$ ) } & \multirow{2}{*}{$\begin{array}{l}\text { Percent } \\
{ }^{14} \mathrm{C} \text { in } \\
\text { backbone }\end{array}$} \\
\hline & Water-soluble & Diacylglycerol & \\
\hline \multicolumn{4}{|l|}{ Wild-type } \\
\hline - Azide & 1500,1272 & 5766,4656 & 79,79 \\
\hline + Azide & 561,785 & 2601,2843 & 82,78 \\
\hline \multicolumn{4}{|l|}{ JBO 52} \\
\hline - Azide & 1094 & 5358 & 83 \\
\hline + Azide & 872,952 & 3129,2788 & 78,75 \\
\hline
\end{tabular}

into phospholipids is present in the backbone of the molecules. Hence, the incorporated radioactivity both in the presence and absence of azide can be used as an indicator of glycerophosphate acyltransferase activity.

Fig. 3 shows the effect of sodium azide on the uptake and subsequent incorporation of glycerol 3-phosphate in phospholipids of wild-type, glycerol 3-phosphate transport-constitutive mutant and glycerol 3-phosphate transport-negative mutant $E$. coli cells. In the case of glycerol 3-phosphate transport-negative cells (Fig. 3C) incorporation of glycerol 3-phosphate is only found in sonicated cell suspensions. Azide has very little effect on this incorporation. In wild-type cells (Fig. 3A) and a glycerol 3-phosphate transport-constitutive mutant (Fig. 3B) azide inhibits the glycerol 3-phosphate incorporation in the phospholipids of intact cells. This is especially noteworthy in mutant cells whose constitutive glycerol 3-phosphate-transport system is apparently more sensitive to inhibition by azide than that of wild-type cells. Inhibition by azide is no longer found in sonicated wild-type cells, suggesting, in agreement with the results of Fig. 3C, that azide inhibits the uptake of glycerol 3-phosphate by the cells and not the glycerophosphate acyltransferase activity itself. The lower activity of glycerol 3-phosphate incorporation found in soni-

TABLE IV

\section{LACK OF EFFECT OF AZIDE ON GLYCEROPHOSPHATE ACYLTRANSFERASE ACTIVITY}

Washed cells or spheroplasts were broken by sonication and incubated for $20 \mathrm{~min}$ in the presence or absence of $20 \mathrm{mM}$ sodium azide in the standard mixture to measure glycerophosphate acyltransferase activity.

\begin{tabular}{|c|c|c|c|c|}
\hline \multirow[t]{3}{*}{ Enzyme source } & \multicolumn{4}{|c|}{$\left[{ }^{14} \mathrm{C}\right]$ Glycero-3-phosphate incorporated (dpm) } \\
\hline & \multicolumn{2}{|c|}{ Lysed cells } & \multicolumn{2}{|c|}{ Lysed spheroplasts } \\
\hline & - azide & + azide & - azide & + azide \\
\hline Wild-type & 524 & 504 & 414 & 421 \\
\hline JBO 52 & 528 & 538 & 488 & 491 \\
\hline LA 5001 & 328 & 368 & 503 & 489 \\
\hline $\begin{array}{l}\text { Wild type, recon } \\
\text { enzyme }\end{array}$ & 415 & 421 & & \\
\hline
\end{tabular}


cates of transport constitutive cells in the presence of azide as compared to sonicates of control cells (Fig. 3B) was found consistently and is difficult to explain. It is certainly not due to inhibition of glycerophosphate acyltransferase activity in these cells by azide. This is directly demonstrated by the data of Table IV. In Table IV the effect of azide on the glycerophosphate acyltransferase in sonicates of either washed cells or spheroplasts prepared from the three different strains was measured. It is obvious that azide exerts no inhibitory effect on the glycerophosphate acyltransferase from either strain. A similar conclusion was drawn from experiments (data not shown) in which isolated membrane vesicles of the three strains were assayed for glycerophosphate acyltransferase activity in the absence and presence of azide. In addition, when the glycerophosphate acyltransferase was solubilized by Triton X-100 extraction of wild-type cells and reconstituted by addition of phospholipid vesicles (Ref. 19 and 'Materials and Methods') no effect of azide on the enzymatic activity was observed (Table IV). Having established that glycerophosphate acyltransferase itself is insensitive to azide the data obtained with intact cells in Fig. 3 can be interpreted in terms of localization of the active site of the enzyme. The absence of glycerol 3-phosphate incorporation in transport negative cells and its inhibition by azide in the other strains implicate the active site of the enzyme being located on the inner aspect of the cytoplasmic membrane. This conclusion is in full agreement with the results of the proteolysis experiments.

\section{Acknowledgements}

The present study was carried out under the auspices of The Netherlands Foundation of Chemical Research (S.O.N.) and with financial aid from the Netherlands Organization for the Advancement of Pure Research (Z.W.O).

\section{References}

1 Raetz, C.R.H. (1978) Microbiol. Rev. 42, 614-659

2 Bell, R.M., Mavis, R.D., Osborn, M.J. and Vagelos, P.R. (1971) Biochim. Biophys. Acta 249 628-635

3 White, D.A., Albright, F.A., Lennarz, W.J. and Schnaitman, C.A. (1971) Biochim. Biophys. Acta 249, 636-642

4 Carman, G.M. and Dowhan, W. (1979) J. Biol. Chem. 254, 8391-8397

5 Louie, K. and Dowhan, W. (1980) J. Biol. Chem. 255, 1124-1127

6 Vance, D.E., Choy, P.C., Farren, S.B., Lim, P.H. and Schneider, W.J. (1977) Nature 270, 268-269

7 Coleman, R. and Bell, R.M. (1978) J. Cell Biol. 76, 245-253

8 Coleman, R.A. and Bell, R.M. (1980) Biochim. Biophys. Acta $595,184-188$

9 Ballas, L.M. and Bell, R.M. (1980) Biochim. Biophys. Acta $602,578-590$

10 Nimmo, H.G. (1979) FEBS Lett. 101, 262-264

11 Carroll, M.A., Morris, P.E., Grosjean, C.D., Anzalone, T. and Haldar, D. (1982) Arch. Biochem. Biophys. 214, 17-25

12 Van den Bosch, H., Williamson, J.R. and Vagelos, P.R. (1970) Nature 228, 338-341

13 Rothman, J.E. and Kennedy, E.P. (1977) Proc. Natl. Acad. Sci. U.S.A. 74, 1821-1825

14 Langley, K.E. and Kennedy, E.P. (1979) Proc. Natl. Acad. Sci. U.S.A. 76, 6245-6249

15 Al-Arif, A. and Blecher, M. (1969) J. Lipid Res. 10, 344-345

16 Lugtenberg, B., Peters, R., Bernheimer, H. and Berendsen, W. (1976) Mol. Gen. Genet. 147, 251-262

17 Argast, M., Ludtke, D., Silhary, T.J. and Boos, W. (1978) J. Bacteriol. 136, 1070-1083

18 Echols, H., Garen, A., Garen S. and Torriani, A. (1961) J. Mol. Biol. 3, 425-438

19 Snider, M.D. and Kennedy, E.P. (1977) J. Bacteriol. 130 , 1072-1083

20 Brunncr, J., Skrabal, P. and Hauser, H. (1976) Biochim. Biophys. Acta 455, 322-331

21 Kaback, H.R. (1971) Methods Enzymol. 22, 99-120

22 Yamato, I., Anraku, Y. and Hirosawa, K. (1975) J. Biochem. 77, 705-718

23 Banerjee, S. and Fraenkel, D.G. (1972) J. Bacteriol. 110, $155-160$

24 Van den Bosch, H. and Vagelos, P.R. (1970) Biochim. Biophys. Acta 218, 233-248

25 Bligh, E.G. and Dyer, W.J. (1959) Can. J. Biochem. Physiol. 37, $911-917$

26 Benns, G. and Proulx, P. (1974) Biochim. Biophys. Acta 337, 318-324

27 Linn, E.C.C. (1976) Annu. Rev. Microbiol. 30, 535-578

28 Nunn, W.D., Cheng, P.J., Deutsch, R., Tang, C.T. and Tropp, B.E. (1977) J. Bacteriol. 130, 620-628

29 Boos, W., Hartig-Beecken, I. and Altendorf, K. (1977) Fur. J. Biochem. 72, 571-581 